\title{
Diallel analysis of some grain yield traits in wheat
}

\author{
Satnam Singh Nagar ${ }^{1}$, Pradeep Kumar ${ }^{2}$, SR Vishwakarma ${ }^{1}$ and Vikas Gupta ${ }^{2}$ \\ ${ }^{1}$ Narendra Deva University of Agriculture and Technology, Faizabad, India \\ ${ }^{2}$ ICAR-Indian Institute of Wheat and Barley Research, Karnal, India
}

\section{Article history}

Received: 19 February, 2018

Revised : 12 April, 2018

Accepted: 22 April, 2018

\section{Citation}

Nagar SS, P Kumar, SR Vishwakarma and V Gupta. 2018. Genetic analysis of grain yield and its component traits using diallel analysis in bread wheat. Wheat and Barley Research 10(1):45-51. doi. org/10.25174/2249-4065/2018/77261

\section{*Corresponding author}

Email: pradeeptaliyan231@gmail.com

(C) Society for Advancement of Wheat and Barley Research

\begin{abstract}
Genetic analysis was conducted for grain yield and its component traits in a set of 13 bread wheat genotypes following a diallel (excluding reciprocals) mating design. The analysis of variance revealed highly significant differences in mean squares due to both general combining ability (GCA) and specific combining ability (SCA) for all the eleven traits in both $F_{1}$ and $F_{2}$ generations. This indicated involvement of both additive and non-additive gene action governing inheritance of traits. The $\sigma^{2} \mathbf{s}$ was higher than $\sigma^{2} \mathrm{~g}$ and the ratio of $\sigma^{2} \mathrm{~g} / \sigma^{2} \mathrm{~s}$ was less than unity (1.00) for all traits, suggesting the importance of non-additive gene action in both $F_{1}$ and $F_{2}$ generation. The parental genotypes NW 1014, PBW 343, PBW 502, DBW 14 and RAJ 3765 were found to be good combiners for multiple traits along with grain yield in both $F_{1}$ and $F_{2}$ generations. The seven crosses PBW 343 / K 8962, UP 2490 / CBW 38, PBW 343 / HI 1563, HP 1744 / UP 2425, HP 1744 / CBW 38, DBW 14 / CBW 38 and RAJ 3765 / UP 2490 were found to be good combiners for grain yield and its contributing multiple traits in both $F_{1}$ and $F_{2}$ generations and these crosses may be utilized in the development of high yielding progenies in bread wheat.
\end{abstract}

Keywords : Combining ability, component traits, gene action, grain yield, half-diallel and bread wheat.

\section{Introduction}

Bread wheat (Triticum aestivum L. $2 \mathrm{n}=6 \mathrm{x}=42$ ) is a selfpollinated crop belonging to Poaceae family and is grown worldwide. At global level, India is the second largest wheat producing nation after China. India accounts for $12.5 \%$ of the total wheat area in the world, whereas it contributes about $12 \%$ in total world wheat production (Anonymous, 2016). In India, the production of wheat has increased manifold from $6.60 \mathrm{mt}$ at the time of independence to $97.44 \mathrm{mt}$ in 2016-17 (Anonymous, 2017). The demand for wheat is increasing with the increase in population. In order to meet out the growing demand of wheat grains, wheat production and productivity must be enhanced. The manifold increase of wheat production in India has mainly been attributed to the development and cultivation of semi dwarf, input responsive and disease resistant varieties. Although, the production of wheat in India has gone up tremendously, but the productivity enhancement is still an issue. Therefore, the most important step in any breeding program is the identification of suitable parents with good combining ability for yield contributing traits and to create genetic variability and gather information about the genetic architecture of component traits. The choice of suitable parents for evolving better varieties/hybrids is a matter of concern to the plant breeders. For this purpose, the combining ability analysis is proven as a powerful tool to discriminate good as well as poor combiners for choosing appropriate parental materials for a particular character. 
It is useful to assess the nicking ability of the parents and at the same time it elucidates the nature and magnitude of different types of gene actions involved and also helpful to identify good general combiners for a series of crosses as well as good specific cross combination for high yield potential, that can be used to achieve maximum genetic improvement in wheat breeding programmes.

In a systematic breeding programme, selection of parents with desirable characteristics having good general combining ability effects for grain yield and its components and high estimates of specific combining ability effects are essential. These estimates will help in formulating sound, efficient and effective breeding procedure to bring about rapid and purposeful improvement in this crop. The general combining ability (GCA) gives information about additive and additive $\mathrm{x}$ additive gene action, whereas specific combining ability (SCA) provides information about the non-allelic interaction and dominance gene action. In addition, diallel analysis gives an opportunity to the plant breeders for choosing the most efficient selection method by allowing them to estimate several genetic parameters by Singh and Chaudhary (1979). Diallel analysis provides a unique opportunity to test a number of lines in all possible combinations. Keeping the above facts under consideration, the present study was undertaken to identify the best general and specific combiners based on their general and specific combining ability for grain yield and its component traits in bread wheat.

\section{Materials and methods}

The base material consisting 13 diverse genotypes of bread wheat namely NW 1014, NW 2036, PBW 502, PBW 343 , K 8962, HI 1563, DBW 14, RAJ 3765, RAJ 4120, HP 1744, UP 2490, UP 2425 and CBW 38 was planted at Main Experiment Station of Narendra Deva University of Agriculture and Technology, Kumarganj, Faizabad (U.P.) during rabi 2012-2013 for attempting crosses following half diallel system. During summer 2013, $F_{1}$ seed of 78 crosses was sent to IARI Regional Research Station, Wellington, Tamil Nadu for generation advancement. In the next crop season (rabi 2013-2014), the final experimental materials comprising of 13 parents along with their $78 \mathrm{~F}_{1} \mathrm{~s}$, and $78 \mathrm{~F}_{2} \mathrm{~s}$ were evaluated following a randomized block design with three replications. Each genotype was planted in a single row plot of $3 \mathrm{~m}$ length with a spacing of $23 \mathrm{~cm}$ and $10 \mathrm{~cm}$ between rows and between plants in a row, respectively.
All the recommended agronomic practices were adopted to raise a good crop. The observations were recorded on five randomly selected plants in parents, 10 plants in $F_{1}$ generation and 20 plants in $F_{2}$ generation for days to $50 \%$ flowering, days to maturity, plant height $(\mathrm{cm})$, spike length $(\mathrm{cm})$, number of effective tillers per plant, number of spikelets per spike, number of grains per spike, 1000grain weight $(\mathrm{g})$, biological yield per plant $(\mathrm{g})$, harvest index $(\%)$ and grain yield per plant $(\mathrm{g})$. Diallel analysis was carried out according to the method described by Mather and Jinks (1982). The analysis of variance was estimated following Panse and Sukhamte (1969). The combining ability analysis was done following method-II, Model-I given by Grifing, (1956).

\section{Results and discussion}

The analysis of variance (ANOVA) for combining ability revealed that the variances due to general combining ability (GCA) and specific combining ability (SCA) were highly significant for all the 11 yield components in both $F_{1}$ and $F_{2}$ generations, depicting the involvement of both additive and non-additive gene action in the inheritance of these traits in both the generations. The magnitude of GCA effects was higher than their respective SCA effects for all the traits studied, revealed preponderance of additive gene action in both $\mathrm{F}_{1}$ and $\mathrm{F}_{2}$ generations. The days to $50 \%$ flowering, number of tillers, plant height, days to maturity, 1000-grain weight, number of grains per spike and grain yield per plant was primarily controlled by additive component of genetic variance under normal conditions (Singh et al., 2014). The estimated value of $\sigma^{2} \mathrm{~s}$ was higher than $\sigma^{2} \mathrm{~g}$ for all the 11 traits under study, indicating predominance of non-additive gene action. The ratio of $\sigma^{2} g / \sigma^{2} \mathrm{~s}$ was less than unity (1.00) for all the yield components, suggesting the importance of nonadditive gene action in the inheritance of these traits in both $F_{1}$ and $F_{2}$ generations (Table 1). The role of both additive and non-additive effects for grain yield and its component traits was also reported by Sheikh et al. (2000); Singh (2003), Singh et al. (2012) and Gautum et al. (2016) in wheat. The average degree of dominance $(\sigma 2 \mathrm{~s} / \sigma 2 \mathrm{~g})^{1 / 2}$ was greater than unity (1.0) for all the traits under study, indicating over-dominance type of gene action, which supports the earlier findings reported by Hassani $e t$ al., (2005). The preponderance of non-additive gene effects was also reported (Chaman et al., 2005 and Heidari et al., 2006) for various yield components in wheat. 


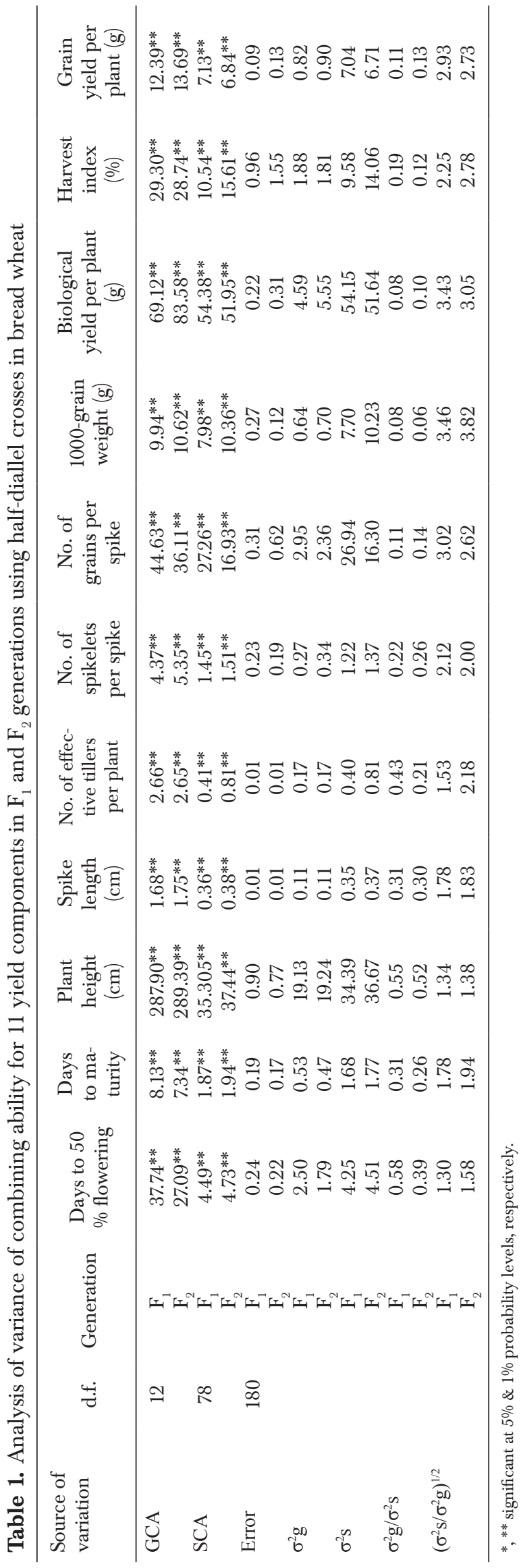

The GCA and SCA variances and effects were estimated with a view to decipher the genetic architecture of the characters under study. Combining ability describes the breeding value of parental lines to produce hybrids (Romanus et al. 2008). Diallel analysis was carried out following the method described by Mather and Jinks (1982) and combining ability analysis was done following Method 2- Model II of Griffing (1956). Selection of suitable genotypes and their crosses in effective hybridization is a pre-requisite in order to formulate a systematic breeding programme leading to rapid and sustained improvement. The combining ability effects (Tables 2 and 3) furnish information on these aspects. Thus, the genetic material available in the present study is suitable for evolving desirable hybrids as well as varieties. In the later case, some sort of inter-mating within segregating progenies at various stages would be more desirable to harness additive and additive $x$ additive type of variance.

In case of GCA effects of parents, none of the parent was identified as good general combiner for all the 11 traits but all parents showed favourable GCA effect for one or more yield components under study in both $\mathrm{F}_{1}$ and $\mathrm{F}_{2}$ generations (Table 2). Out of 13 parents, NW 1014 was found to be a good general combiner for days to $50 \%$ flowering, days to maturity, spike length, effective tillers per plant, number of grains per spike, 1000-grain weight, biological yield per plant and grain yield per plant in both $\mathrm{F}_{1}$ and $\mathrm{F}_{2}$ generation; PBW 343 for plant height, number of effective tillers per plant, 1000-grain weight, biological yield per plant and grain yield per plant; PBW 502 for plant height, spike length, number of effective tillers per plant, 1000-grain weight, harvest index and grain yield per plant, DBW 14 for days to maturity, plant height, number of grains per spike, number of spikelets per spike, biological yield per plant and grain yield per plant, RAJ 3765 for days to 50\% flowering, plant height, spike length, number of spikelets per spike, number of grains per spike, 1000-grain weight, biological yield per plant and grain yield per plant in both $\mathrm{F}_{1}$ and $\mathrm{F}_{2}$ generation. Therefore, these parental lines can be used in crossing programme for improvements in grain yield and its component in bread wheat. High GCA effects are mostly due to additive gene effects and/or additive $\times$ additive interaction effects (Griffing, 1956). In view of this, breeders may utilize the good general combiners in 
specific breeding programme for improvement in grain yield. It is therefore recommended that the breeder should breed for superior combining ability for the component traits with an ultimate objective to improve the overall GCA for grain yield in bread wheat. In order to synthesize a dynamic population with most of the favorable genes accumulated, it will be pertinent to make use of these parents, which are good general combiner for several traits in multiple crossing programmes. In contrast to the conventional breeding methods which are relying mainly on additive or additive $\times$ additive types of gene action, population improvement appears to be a promise alternative.

In the present study, among the 78 crosses, top seven crosses were selected based on significant and desirable SCA effects for higher grain yield and also for other yield component in both $\mathrm{F}_{1}$ and $\mathrm{F}_{2}$ generations (Table 3). The findings of the present study indicated that the best combinations mostly involved high $\times$ low and low $\times$ low general combiners for the studied characters. In few best cross combinations, high $\times$ high general combiners were involved. Similar type of results was also reported by Singh et al. (2012); Kumar and Maloo (2012); Kumar et al. (2016); Kumar et al. (2017) in wheat. Thus, it is evident that good specific combiners are not always obtained between high general combiners but may be obtained between low $\times$ low or high $\times$ low general combiners. This might be probably due to the presence of dominant and epistatic gene interactions.

With respect to the specific combining ability effects, thirty nine crosses exhibited significant and positive SCA effects for grain yield per plant in both $\mathrm{F}_{1}$ and $\mathrm{F}_{2}$ generations. There are some promising crosses exhibiting highest significant and desirable SCA effects for grain yield per plant, also had significant SCA effects for some other yield component as well. For instance, the cross PBW 343 / K 8962 recorded the highest significant SCA effect for grain yield per plant, also had significant SCA effects for plant height, number of effective tillers per plant, number of spikelets per plant, number of grains per spike, 1000-grain weight, biological yield per plant and harvest index; UP 2490 / CBW 38 for grain yield along with days to $50 \%$ flowering, spike length, number of grains per spike, 1000-grain weight and biological yield per plant; PBW 343 / HI 1563 for grain yield along with

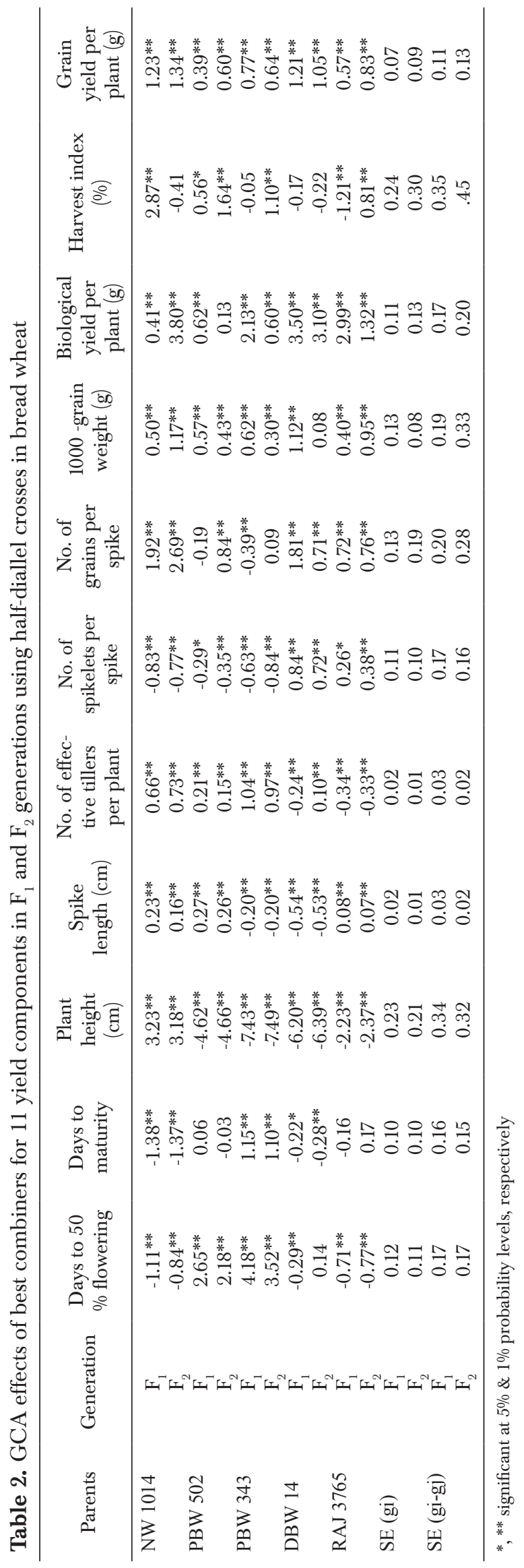


days to $50 \%$ flowering, days to maturity, plant height, number of effective tillers per plant, number of spikelets per plant, 1000-grain weight and biological yield per plant; HP 1744 / UP 2425 for grain yield along with days to $50 \%$ flowering, days to maturity, plant height, number of grains per spike, number of effective tillers per plant, 1000-grain weight and biological yield per plant; HP 1744 / CBW 38 for grain yield along with plant height, number of grains per spike and biological yield per plant; DBW 14 / CBW 38 for grain yield along with days to maturity, plant height, number of grains per spike, 1000-grain weight and biological yield per plant and RAJ 3765 / UP 2490 for grain yield along with days to 50\% flowering, plant height, number of grains per spike, number of effective tillers per plant, 1000-grain weight and biological yield per plant in both $\mathrm{F}_{1}$ and $\mathrm{F}_{2}$ generations.

Table 3. SCA effect of best combiners for 11 yield components in $\mathrm{F}_{1}$ and $\mathrm{F}_{2}$ generations using half-diallel crosses in bread wheat

\begin{tabular}{lccccccccccccc}
\hline Trait & \multicolumn{2}{c}{$\begin{array}{c}\text { Days to 50 } \% \\
\text { flowering }\end{array}$} & \multicolumn{2}{c}{$\begin{array}{c}\text { Days to } \\
\text { maturity }\end{array}$} & \multicolumn{2}{c}{$\begin{array}{c}\text { Plant height } \\
(\mathrm{cm})\end{array}$} & \multicolumn{2}{c}{$\begin{array}{c}\text { Spike length } \\
(\mathrm{cm})\end{array}$} & $\begin{array}{c}\text { No. of effective } \\
\text { tillers per plant }\end{array}$ & $\begin{array}{c}\text { No. of spikelets } \\
\text { per spike }\end{array}$ \\
\hline Crosses & $\mathrm{F}_{1}$ & $\mathrm{~F}_{2}$ & $\mathrm{~F}_{1}$ & $\mathrm{~F}_{2}$ & $\mathrm{~F}_{1}$ & $\mathrm{~F}_{2}$ & $\mathrm{~F}_{1}$ & $\mathrm{~F}_{2}$ & $\mathrm{~F}_{1}$ & $\mathrm{~F}_{2}$ & $\mathrm{~F}_{1}$ & $\mathrm{~F}_{2}$ \\
\hline PBW 343 / K 8962 & $3.06^{* *}$ & $3.18^{* *}$ & $0.85^{*}$ & $1.51^{* *}$ & $-7.80^{* *}$ & $-6.93^{* *}$ & $-0.38^{* *}$ & $-0.26^{* *}$ & $0.77^{* *}$ & $0.97^{* *}$ & 0.07 & 0.10 \\
PBW 343 / HI 1563 & $-1.00^{*}$ & $-1.07^{*}$ & -0.33 & $-1.89^{* *}$ & $-6.58^{* *}$ & $-7.20^{* *}$ & 0.12 & 0.03 & $0.95^{* *}$ & $0.78^{* *}$ & 0.36 & 0.06 \\
DBW 14 / CBW 38 & 0.84 & 0.51 & $-2.09^{* *}$ & $-2.17^{* *}$ & $-10.56^{* *}$ & $-11.36^{* *}$ & -0.14 & $-0.29^{* *}$ & 0.13 & $3.20^{* *}$ & $-1.93^{* *}$ & $-1.88^{* *}$ \\
RAJ 3765 / UP 2490 & $-1.36^{* *}$ & $-1.31^{* *}$ & -0.46 & 0.29 & $-4.22^{* *}$ & $-4.52^{* *}$ & 0.15 & -0.04 & -0.10 & 0.08 & $-1.11^{*}$ & $-1.23^{* *}$ \\
HP 1744 / UP 2425 & -0.27 & $-1.82^{* *}$ & $-0.95^{*}$ & -0.69 & $-5.59^{* *}$ & $-7.29^{* *}$ & $-0.79^{* *}$ & $-0.82^{* *}$ & $0.19^{*}$ & $0.25^{* *}$ & 0.03 & -0.08 \\
HP 1744 / CBW 38 & $1.47^{* *}$ & $1.49^{* *}$ & $-1.20^{* *}$ & 0.14 & $-4.48^{* *}$ & $-4.34^{* *}$ & $-0.42^{* *}$ & $-0.73^{* *}$ & 0.01 & $-0.20^{* *}$ & 0.10 & 0.37 \\
UP 2490 / CBW 38 & -0.89 & $-2.20^{* *}$ & 0.71 & $-1.89^{* *}$ & $17.24^{* *}$ & $15.25^{* *}$ & $0.95^{* *}$ & $1.29^{* *}$ & $0.81^{* *}$ & $0.86^{* *}$ & $2.36^{* *}$ & $3.06^{* *}$ \\
SE (Sij) & 0.45 & 0.44 & 0.41 & 0.38 & 0.90 & 0.82 & 0.08 & 0.07 & 0.08 & 0.06 & 0.44 & 0.41 \\
SE (Sij-Sik) \pm & 0.67 & 0.64 & 0.60 & 0.56 & 1.30 & 1.20 & 0.12 & 0.10 & 0.12 & 0.09 & 0.65 & 0.60 \\
\hline
\end{tabular}

\begin{tabular}{lcccccccccc}
\hline Trait & \multicolumn{2}{c}{$\begin{array}{c}\text { No. of grains per } \\
\text { spike }\end{array}$} & \multicolumn{2}{c}{$\begin{array}{c}\text { 1000 -grain } \\
\text { weight }(\mathrm{g})\end{array}$} & \multicolumn{2}{c}{$\begin{array}{c}\text { Biological yield per } \\
\text { plant }(\mathrm{g})\end{array}$} & \multicolumn{2}{c}{$\begin{array}{c}\text { Harvest index } \\
(\%)\end{array}$} & \multicolumn{2}{c}{$\begin{array}{c}\text { Grain yield per plant } \\
(\mathrm{g})\end{array}$} \\
\hline Crosses & $\mathrm{F}_{1}$ & $\mathrm{~F}_{2}$ & $\mathrm{~F}_{1}$ & $\mathrm{~F}_{2}$ & $\mathrm{~F}_{1}$ & $\mathrm{~F}_{2}$ & $\mathrm{~F}_{1}$ & $\mathrm{~F}_{2}$ & $\mathrm{~F}_{1}$ & $\mathrm{~F}_{2}$ \\
\hline PBW 343 / K 8962 & $10.26^{* *}$ & $6.20^{* *}$ & $5.65^{* *}$ & $4.45^{* *}$ & $11.56^{* *}$ & $15.71^{* *}$ & $4.36^{* *}$ & $-2.66^{*}$ & $6.03^{* *}$ & $4.96^{* *}$ \\
PBW 343 / HI 1563 & -0.74 & $6.42^{* *}$ & $2.31^{* *}$ & $5.94^{* *}$ & $10.06^{* *}$ & $9.55^{* *}$ & $2.73^{* *}$ & 1.93 & $5.13^{* *}$ & $4.73^{* *}$ \\
DBW 14 / CBW 38 & $5.92^{* *}$ & $3.31^{* *}$ & $2.24^{* *}$ & $2.63^{* *}$ & $9.13^{* *}$ & $1.41^{* *}$ & -0.36 & $7.04^{* *}$ & $3.31^{* *}$ & $3.09^{* *}$ \\
RAJ 3765 / UP 2490 & $4.21^{* *}$ & $4.00^{* *}$ & $2.48^{* *}$ & $1.57^{* *}$ & $10.36^{* *}$ & $9.58^{* *}$ & -0.52 & -2.17 & $3.90^{* *}$ & $3.05^{* *}$ \\
HP 1744 / UP 2425 & $3.86^{* *}$ & $2.55^{* *}$ & $1.37^{* *}$ & $2.24^{* *}$ & $9.31^{* *}$ & $6.20^{* *}$ & 1.01 & $4.04^{* *}$ & $3.85^{* *}$ & $4.19^{* *}$ \\
HP 1744 / CBW 38 & $6.66^{* *}$ & $2.93^{* *}$ & 0.78 & $2.13^{* *}$ & $9.38^{* *}$ & $10.46^{* *}$ & 1.04 & 1.00 & $3.94^{* *}$ & $4.62^{* *}$ \\
UP 2490 / CBW 38 & $11.68^{* *}$ & $10.49^{* *}$ & $2.92^{* *}$ & $4.20^{* *}$ & $14.27^{* *}$ & $7.96^{* *}$ & -0.76 & $3.81^{* *}$ & $5.18^{* *}$ & $4.68^{* *}$ \\
SE (Sij) \pm & 0.52 & 0.74 & 0.50 & 0.33 & 0.44 & 0.52 & 0.91 & 1.16 & 0.29 & 0.34 \\
SE (Sij-Sik) \pm & 0.77 & 1.08 & 0.72 & 0.48 & 0.64 & 0.76 & 1.33 & 1.70 & 0.42 & 0.50 \\
\hline
\end{tabular}

${ }^{*},{ }^{* *}$ significant at $5 \% \& 1 \%$ probability levels, respectively

The improvement in traits exhibiting dominance/ non-additive gene effects will be achieved by methods exploiting non-additive gene actions, such as restricted recurrent selection by way of inter-mating the most desirable segregants followed by selection or multiple crosses/bi-parental mating in early segregating generations. Heterosis breeding is also an effective breeding strategy for exploiting non-additive gene effects. The traits showing predominance of non-additive gene effects indicates that the improvement of such trait would be difficult, as simple pedigree breeding will not be able to fix the superior lines in the early generations. In such situation, maintaining considerable heterozygosity through mating of selected plants in early segregating generations could attain maximum gain. Therefore, few cycles of recurrent selection followed by pedigree breeding will be effective and useful for the improvement of yield in such cases as in the present material.

Grain yield is a complex trait controlled by polygenes and due to predominance of non-additive gene action, it would be worthwhile to resort to breeding methodologies, such as bi-parental mating, recurrent selection and diallel selective mating rather than to use of conventional pedigree or backcross breeding techniques. Diallel selective mating system is good technique, which delays quick fixation of gene complexes and permits break down of linkage, 
general fostering of recombination and concentration of favorable gene complexes into central gene pool by a series of multiple crosses. The SCA represents the dominance and epistatic interaction, which can be related with heterosis. However, in self-pollinated crops like wheat, the additive $\times$ additive type epistasis is fixable in later generations. Jinks and Jones (1958) emphasized that the superiority of hybrids might not indicate their ability to yield transgressive segregants rather SCA would provide satisfactory criteria.

The present study demonstrates that both additive (fixable) and non-additive (non fixable) components of genetic variance were involved in governing the inheritance of grain yield and component traits in the present set of breeding material. Therefore, bi-parental mating and diallel selective mating would be useful to exploit both type of gene action (additive and non-additive). The parental genotypes DBW 14, PBW 343, NW 1014, RAJ 3765 and PBW 502 showed good GCA effects for grain yield along with multiple yield components therefore these genotypes may be utilized further in hybridization to improve yield in wheat crop. Inclusion of $\mathrm{F}_{1}$ hybrids showing high SCA and having parents with good GCA into multiple crosses could also be a worthwhile approach for tangible improvement of grain yield in bread wheat. The generated material through presented study can be used in future wheat breeding programme to develop high yielding wheat genotypes.

\section{References}

1. Anonymous. 2017. Annual Report 2016-17, ICARIndian Institute of Wheat \& Barley Research, Karnal-132001, Haryana, India.

2. Anonymous. 2016. Progress Report of All India Coordinated Wheat and Barley Improvement Project, 1-5 pp G. P. Singh (Ed). Indian Institute of Wheat and Barley Research, Karnal.

3. Chaman S, SK Gupta and DR Satija. 2005. Genetic architecture for some quality traits in wheat (T. aestivum L.). Indian Journal of Genetics and Plant breeding 65(4): 278-80.

4. Gautam A, SV Sai, D Ambati and A Jajoo. 2016. Genetic analysis of grain yield and its contributing components in diallel crosses of durum wheat
(Triticum durum L.) under terminal heat stress conditions. Journal of Wheat Research 8(2):12-18.

5. Griffing B. 1956. Concept of general and specific combining ability in relation to diallel crossing systems. Australian Journal of Biological Science 9: 463493.

6. Hassani M, G Saeidi and A Rezai. 2005. Estimation of genetic parameters and combining ability for yield and yield components in bread wheat. Journal of Science and Technology of Agriculture and Natural Resources 9(1):157-171.

7. Heidari B, A Rezai and SAMM Maibody. 2006. Diallel analysis for the estimation of genetic parameters for grain yield and grain yield components in bread wheat. Journal of Science and Technology of Agriculture and Natural Resources 10(2): 121-140.

8. Jinks JL and Jones RM. 1958. Estimation of components of heterosis. Genetics 43: 223-234.

9. Kumar Pradeep, Gyanendra Singh, Devi Singh and Anil Sirohi. 2016. Genetic architecture of various agromorphological and some quality traits in bread wheat (Triticum aestivum L). Indian Journal of Agricultural Sciences 86(12): 1530-1535.

10. Kumar S, P Kumar, G Singh and SA Kerkhi. 2017. Genetic analysis for various agromorphological and quality traits in bread wheat (Triticum aestivum). Indian Journal of Agricultural Sciences 887(10): 69-75.

11. Kumar V and SR Maloo. 2012. Parental molecular diversity and its concurrence to heterosis in bread wheat (Triticum aestivum). Indian Journal of Agricultural Sciences 82(3): 207-212.

12. Mather K and JL Jinks. 1982. Biometrical Genetics: The Study of Continuous Variation. Chapman and Hall Inc., London.

13. Panse VG and PV Sukhatme. 1969. Statistical Methods of Agricultural Workers. 2nd Endorsement, ICAR Publication, New Delhi, India, pp: 381.

14. Romanus KG, S Hussein and WP Mashela. 2008. Combining ability analysis and association of yield and yield components among selected cowpea lines. Euphytica 162: 205-210. 
15. Sheikh S, I Singh and J Singh. 2000. Inheritance of some quantitative traits in bread wheat (Triticum aestivum L.). Annals of Agriculture Research 21: 51-54.

16. Singh MK, PK Sharma, BS Tyagi and G Singh. 2014. Combining ability analysis for yield and protein content in bread wheat (Triticum aestivum L.). Indian Journal of Agricultural Sciences 84: 328-336.

17. Singh RK and BD Chaudhary. 1979. Biometrical Methods in Quantitative Genetic Analysis. Kalyani Publisher, New Delhi. Pp318.
18. Singh H, N Sharma, RS Sain and DL Singhania. 2003. The inheritance of production traits in bread wheat by diallel analysis. SABRAO Journal of Breeding and Genetics 35(1):1-9.

19. Singh V, R Krishna, S Singh and P Vikram. 2012. Combining ability and heterosis analysis for yield traits in bread wheat (Triticum aestivum L.). Indian Journal of Agricultural Sciences 82(11):916-912. 